\title{
Author Correction: Single cell transcriptomics identifies stem cell-derived graft composition in a model of Parkinson's disease
}

\author{
Katarína Tiklová, Sara Nolbrant (B), Alessandro Fiorenzano, Åsa K. Björklund (D), Yogita Sharma, Andreas Heuer (D), \\ Linda Gillberg, Deirdre B. Hoban, Tiago Cardoso (1), Andrew F. Adler, Marcella Birtele, Hilda Lundén-Miguel, \\ Nikolaos Volakakis, Agnete Kirkeby, Thomas Perlmann \& Malin Parmar (1)
}

Correction to: Nature Communications https://doi.org/10.1038/s41467-020-16225-5, published online 15 May 2020.

The original version of this Article contained an error in the Acknowledgments, which incorrectly read "The research leading to these results has received funding from the New York Stem Cell Foundation (to M.P.), the European Research Council (ERC Grant Agreement no. 30971, to M.P.), the Swedish Research Council [grant agreements 521-2012-5624 (to M.P.), 2016-02506 (to T.P.) and 70862601/Bagadilico)], Swedish Parkinson Foundation (Parkinsonfonden, to M.P.), Swedish Brain Foundation (Hjärnfonden, to M.P.), the Strategic Research Area at Lund University Multipark (Multidisciplinary research in Parkinson's disease), StratRegen grant Karolinska Institutet (to T.P.); Knut and Alice Wallenberg Foundation (to T.P.), Söderbergs Stiftelse (to T.P.) and Svenska Sällskapet för Medicinsk Forskning (to K.T.). M.P. is a New York Stem Cell Foundation-Robertson Investigator.'

The correct version states 'ERC Grant Agreement no. 771427, to M.P.' in place of 'ERC Grant Agreement no. 30971, to M.P.'

This has been corrected in both the PDF and HTML versions of the Article.

Published online: 15 July 2020

\footnotetext{
(c) (i) Open Access This article is licensed under a Creative Commons Attribution 4.0 International License, which permits use, sharing, adaptation, distribution and reproduction in any medium or format, as long as you give appropriate credit to the original author(s) and the source, provide a link to the Creative Commons license, and indicate if changes were made. The images or other third party material in this article are included in the article's Creative Commons license, unless indicated otherwise in a credit line to the material. If material is not included in the article's Creative Commons license and your intended use is not permitted by statutory regulation or exceeds the permitted use, you will need to obtain permission directly from the copyright holder. To view a copy of this license, visit http://creativecommons.org/licenses/by/4.0/.
}

(C) The Author(s) 2020 